\title{
Economic Consequences of Insect Pests Outbreaks in Boreal Forests: A Literature Review
}

\author{
Ekaterina D. Ivantsova, Anton I. Pyzhev \\ and Evgeniya V. Zander* \\ Siberian Federal University \\ 79 Svobodny, Krasnoyarsk, 660041, Russia
}

Received 23.04.2019, received in revised form 26.04.2019, accepted 17.04.2019

Outbreaks of pests are considered one of the most destructive types of natural forest disorders. In recent years the severity of such outbreaks has rapidly increased due to the process of global warming, which affects the rate of reproduction of pests and the range of their natural distribution. Economic consequences of these types of disturbances are of particular importance. Though many studies have been conducted in the field of tree phytophages ecology, the issues of estimating economic damage and the formation of mechanisms for its minimization have been poorly studied. This article presents a review of studies on the problem of the harmful effects of forest pests classified by their localization. The area of study includes mainly boreal forests located in a number of European countries, the USA, Canada and Russia. Our study reviews the range of instruments applied to prevent disturbances mentioned above and mitigate corresponding negative consequences. Despite the fact that there are theoretical approaches to the analysis of the economic consequences of forest damage by pests, they still cannot find practical application.

Keywords: forest economics, forest disturbances, pest outbreaks, climate change, boreal forests, forest management.

The research was partially supported by the grant of the President of the Russian Federation to support young Russian scientists no. MK-3482.2018.6 (analysis of relation between climate change and distribution of insect pests, discussion of economics of invasive forest) and the Russian Science Foundation project no. 19-77-30015 (classification of the main strategies of insect pest management).

Research area: economics.

Citation: Ivantsova, E.D., Pyzhev, A.I., Zander, E.V. (2019). Economic Consequences of Insect pests outbreaks in boreal forests: a literature review. J. Sib. Fed. Univ. Humanit. soc. sci., 12(4), 627-642. DOI: 10.17516/1997-1370-0417.

(C) Siberian Federal University. All rights reserved

* Corresponding author E-mail address: pyanist@ya.ru

ORCID: 0000-0002-3963-0080 (Ivantsova); 0000-0001-7909-3227 (Pyzhev); 0000-0002-2135-5084 (Zander)

This work is licensed under a Creative Commons Attribution-NonCommercial 4.0 International License (CC BY-NC 4.0). 


\section{Introduction}

Ecological disturbances of forests caused by insect pests are a serious threat to both natural ecosystems and human welfare. Furthermore, other types of biotic and abiotic forest disturbances are often followed by bark beetles' outbreaks. Damages and losses caused by insect outbreaks have an increasing trend in recent decades due to global climate change and related natural disturbances.

In Russia, where forest lands cover more than a half of the national territory, disturbances, such as wildfires and pests' outbreaks, are a threatening menace to forest ecosystems from economic perspective, including reduction of goods and services provided by forests. Even though the total forest area affected by pests is decreasing through past 14 years, the area of forest affected by conifer-consuming pests has been rapidly increasing: from 353.3 thousand ha in 2005 to 1117.7 thousand ha in 2017. Increasing trend is also observed in total forest area affected by wildfires: it raised by more than $67 \%$ from 2010 to 2017. Similar changes have been observed in many countries of the boreal zone.

It is clear that insect pests' outbreaks could become the major factor that constrains the development of Russian forest economy. Despite the fact that the ecology of main insect pests of Russian forests is described in detail, there is still no studies that analyse the economic consequences of forest damage and design the policies to face this challenge. In this article we aim to reveal the key results on insect pest management strategies for different species and to give an overview of the main analytical frameworks to model the optimal economic mechanism of forest exploitation subject to the diseases caused by insect pests' activity.

Though many studies have been dedicated to the issue of bark beetles' outbreaks as an ecological problem, there is still a lack of systematic review studies that would form a complete representation of consequences, especially from the economic perspective, as well as ways of prevention and mitigation of forest disturbances by insect pests.

We aim to review the studies of the problem of forest disturbances by insect pests, defining the characteristics of the most common species outbreaks, the ways of preventing these disturbances and mitigating the damages connected with these disturbances.

Our study consists of three parts. The first part provides the definition of insect pests management tactics in general. The review of pest management interventions research is presented in the second part. Finally, the third part includes classification of insect pest management strategies by the region of disturbance. 


\section{Climate change and distribution of insect pests}

There is no doubt that the global warming process is developing along with an increasing number of abiotic disturbances, which, in turn, increases bark beetle activity (Thom, Rammer \& Seidl, 2017). Increases in temperatures on the globe during the past century are significant in the context of possible expansion of distribution range of some species. For instance, Polygraphus proximus that had attacked fir forests in Western Siberia, successfully acclimatized itself and became a full member of the local fauna (Kerchev, 2014). Another example can be found in the Czech Republic, where expected climate changes will lead to significantly enlarged ranges of Lymantria dispar and Ips typographus outbreaks (Hlásny et al., 2017).

Higher temperatures also affect the reproduction rate of bark beetles. Studies across Scandinavia show that I. typographus, one of the most important pests of spruce forests, and some other species, such as Polygraphus polygraphus and Pityogenes chalcographus, may reproduce twice a year if the climate continues to get warm in future (Hof \& Svahlin, 2016; Schlyter et al., 2006). The same shift could happen in lowland parts of Central Europe, where improving climatic conditions can result in increased frequency and length of late summer beetles swarming events producing a third generation of I. typographus (Jönsson et al., 2011).

The consequences of the changes mentioned above and their severity determine the significance of conducting a review in the field of forest disturbances by insect pest. As the climate change induces increase in disturbance activity, forest management is now facing serious challenges. Severity of recent outbreaks in boreal forests throughout the world emphasizes the need of forest management to focus more on the abiotic disturbance-related events and their consequences.

\section{Insect pest management strategies}

Management strategies for bark beetles in boreal forests could be generally classified into four broad categories: a) detection and survey, b) risk and hazard rating, c) direct control and d) indirect control measures (Fettig \& Hilszczański, 2015).

Some specific detection methods are required to gain information about the intensity and extent of insect outbreak. Further, this information is used to design management strategies appropriately. These methods include aerial and ground-based inventories. The first ones involve, e.g., digital sketch-mapping, usually using an aircraft equipped with a global positioning system. Aerial surveys are widely used to detect the infestation followed by more detailed ground-based surveys that are aimed at identifying currently 
infested trees. During beetles' outbreaks specially trained observers are employed to search for infested trees marking, numbering and mapping them. These procedures are usually followed by either debarking or cutting marked trees.

Risk and hazard rating systems are used to estimate the probability of trees infestation, which defines "risk", as well as to predict the extent of tree mortality, which defines "hazard".

Most of the direct control strategies in response to bark beetles' outbreaks are aimed at reducing insect populations slowing their rate of spread, and protecting trees. The direct control measures include acoustic technologies, biological control using natural enemies, cultural measures such as sanitation and salvage, insecticides, fire, and semiochemicals, such as attractants and inhibitors. A group of management interventions that involves indirect control includes thinning, landscape heterogeneity strategies concerning diversity of age, size, and species compositions, and prescribed fire, which is used to reduce surface of fire-prone forests.

The results of the review on the studies dedicated to insect pest management are presented in Table 1, classified by region of the studied disturbance. The study area includes mostly boreal forests located in some regions of Europe, the USA, Canada and Russia. Consequently, the most common tree species are Norway spruce Picea abies, European beech Fagus sylvatica, Scots pine Pinus sylvestris and silver fir Abies alba. It should be noticed that the tree species range in North America differs completely from those in European regions. Besides, most of corresponded studies in Russia concern bark beetle attacks on Siberian fir Abies sibirica.

A variety of different bark beetle species is presented in the reviewed studies. While most of them are strongly committed to specific tree species, the observation results look similar to tree species representation: studies carried out in North America and Europe are dedicated to completely different range of species. Moreover, we should notice specific species in Russia, where Polygraphus proximus becomes the main threat for Siberian fir forests. In Europe, Ips typographus is regarded as the most important pest of $P$. abies. It is also Pityogenes chalcographus that is recognized in this regard as well. In the context of the insect pest management our aim is to highlight the most common and effective management interventions in order to form a basic understanding of current and evolving strategies for both preventing pest outbreaks and mitigating the negative impacts of bark beetles on forests.

In European regions, where P. abies prevails in forest stands, I. typographus is one of the economically most important forest pests. It usually attacks trees that are 


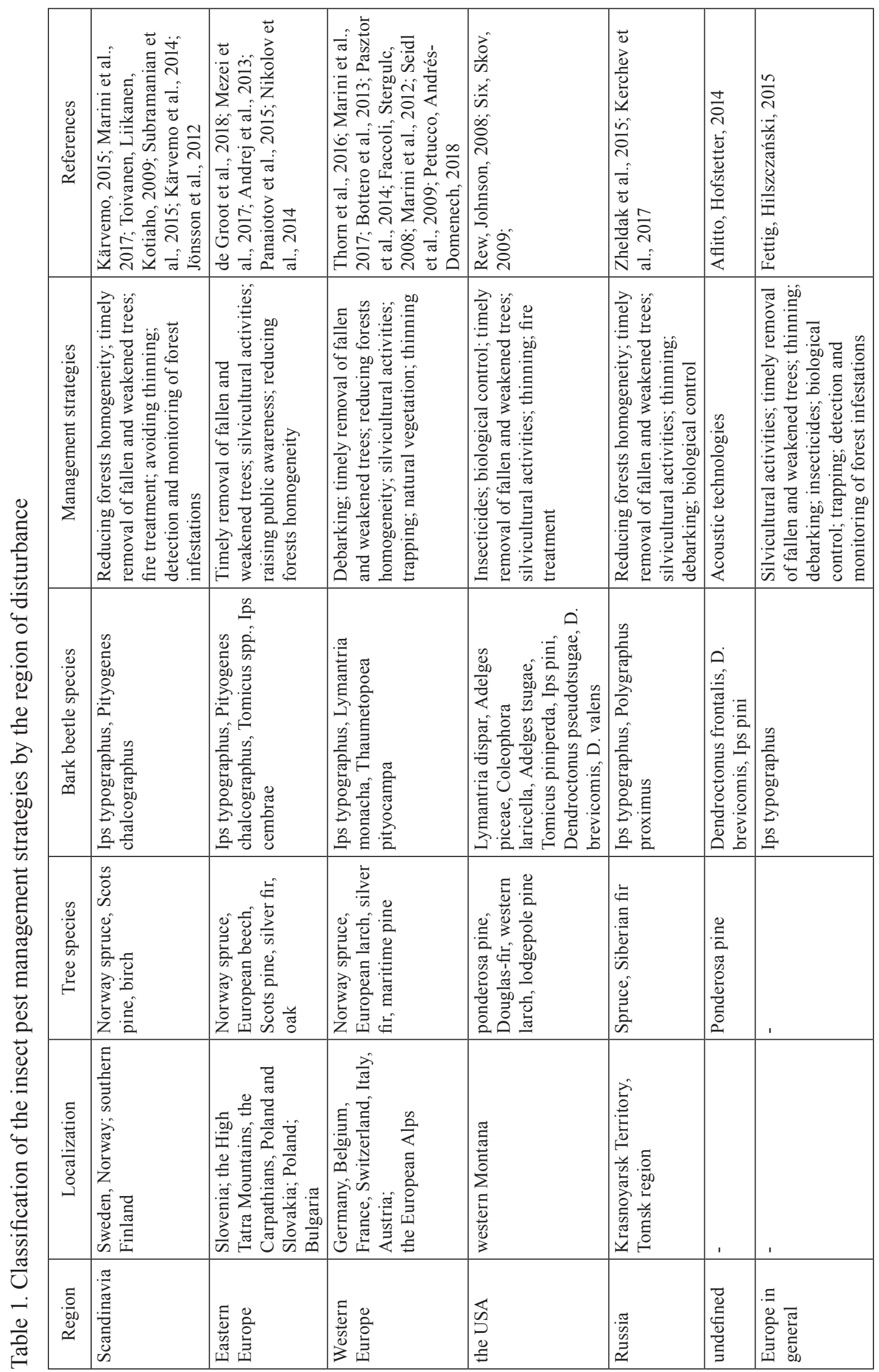


weakened due to stress or recently died. Thus, an effective forest protection strategy should involve timely removal of fallen and weakened trees after disturbances. There is no doubt that abiotic disturbances such as windstorms and droughts affect the abundance of bark beetles as fallen or weakened trees represent brood material. Corresponding management interventions include minimizing availability of stormfelled and stressed standing trees, and besides, areas with numerous large storm gaps should be harvested first (Kärvemo, 2015; Marini et al., 2017). It was also claimed that particularly concerning ice storms removal of fallen trees should be completed before the second year after a large disturbance (de Groot, Ogris, \& Kobler, 2018). Moreover, gathering coarse woody debris strongly influences tree regeneration especially immediately after the disturbance event as woodpiles have a negative influence on forest regeneration hindering the establishment of new seedlings (Bottero et al., 2013).

Biological control is also widely mentioned in the context of bark beetles control measures. Insect pest populations can be regulated at endemic levels through the use of their natural enemies: insect parasitoids and predators, pathogens and woodpeckers. Some species predators and parasitoids show clear habitat preferences, which can be manipulated with the view of the natural enemy control enhancement. To date, biological control measures implemented for I. typographus have not been formally settled, although some authors believe that the recent experiment have proven promising (Fettig \& Hilszczański, 2015). In the USA, most insect research is primarily focused on using insecticides and biological control. Management interventions aimed at manipulating insects' populations in terms of biological control involve increasing predator and parasite habitat or success (Rew \& Johnson, 2008). However, there is still a lack of research on the effectiveness of these treatments. Several researchers observed biological control measures applied to P. proximus populations in the regions of Siberia, Russia. It is claimed that the limited quantity of $P$. proximus natural enemies (endoparasites of beetles and ectoparasites of larvae, larvae of bark beetles, beetles and larvae of small sparrows, birds, particularly woodpeckers) conditions low level of such measures applicability. Nevertheless, there was also a positive experience of P. proximus biological control in Western Siberia. Treatment with fungi Beauveria bassiana and Isaria farinosa demonstrated a mortality level of $P$. proximus adults up to $80-100 \%$ within 5 days even at low temperatures $\left(5^{\circ} \mathrm{C}\right)$, which was reached within 45 days (Kerchev et al., 2017).

One of the most frequently mentioned factors in the context of forest protection management is that mixed tree-species and uneven-aged stands reduce the risk of 
bark beetles killing trees and risks of storm-felling (Kärvemo, 2015; Panaiotov et al., 2015; Pasztor et al., 2014; Zheldak, Malakhova \& Proka, 2015). A significant increase in beetles' population is not likely to happen in forests composed of several species and different sizes of trees, so it is important to reduce the stands homogeneity. It was proved that even-aged $P$. abies forests older than 120 years are at highest risk of large-scale beetles' outbreaks and other natural disturbances (Panaiotov et al., 2015). Reducing the homogeneity of forest age can be reached through reforestation activities as well as through reducing the rotation length. This kind of measures reduces the risk of disturbance-related damages as the intensity of mentioned risk factors increases with age of forest stands (Pasztor et al., 2014). Damages due to natural forest disturbances are also correlated with thinning operations: intensity of natural risks increases soon after thinnings (Subramanian et al., 2015). Such conclusion is supported with the statement that silvicultural measures should avoid sudden opening of the canopy and creation of sun-exposed stand edges (Pasztor et al., 2014). However, the opinions on the effectiveness of thinnings are uncertain. Many researchers consider that thinning operations are a useful forest protection instrument as its application results in low post-treatment mortality of trees due to insect pests in a non-outbreak phase and, in general, creates a hedging strategy against both bark beetles outbreaks and windstorm risks (Petucco \& Andrés-Domenech, 2018; Six \& Skov, 2009; Zheldak et al., 2015). The uncertainty of mentioned results could be caused by differences in conditions of these silvicultural activities application and the goals of forest management. It also depends on the most common disturbance-related threats for the region. Avoiding thinning operations reduces risks of storm damage due to increased stand density and lessens the exposure of stand to root rot fungus, but it also increases risks of natural mortality in stand, and causes lack of early income from thinning, which could be a forest manager goal (Subramanian et al., 2015). Moreover, such indirect control measures as thinnings are the most acceptable for the long-term implications.

Mechanical bark treatments, such as debarking and bark-scratching disturbanceaffected trees, are promoted as methods that correspond to the forest biomass conservation targets. Still, it is difficult to achieve adequate levels of control during pest outbreaks. Even though it was proved that debarking kills over $90 \%$ of $I$. typographus beneath the bark, it was claimed expensive and time consuming (Fettig \& Hilszczański, 2015). However, according to a research conducted in Siberian region of Russia, debarking could be the only effective way of combating $P$. proximus in local Siberian fir forests, because many other direct control measures were claimed 
ineffective or difficult to apply due to biological or economic reasons (Kerchev et al., 2017). In this context, it is recommended to cut freshly populated trees during the winter period, their debarking and burning of logging residues, since $P$. proximus winters in the bark of damaged trees. Although debarking is recognized as one of the most effective measures of the bark beetle direct control, bark-scratching is considered to be an alternative that is significantly less time consuming. Both debarking and barkscratching are aimed at reducing the species density of wood-inhabiting fungi, beetles, and parasitoid wasps. It was proved that both these methods result in decreasing the number of I. typographus to $4 \%$ (debarked) and $11 \%$ (scratched bark) of the number of individuals emerging from untreated control P. abies trees (Thorn et al., 2016). The application of these methods also significantly reduced the number of wood wasps emergence holes and holes made by foraging woodpeckers. Thus, it was concluded that debarking and bark-scratching should be applied only if pest management is urgently needed.

Generally speaking, reducing forests homogeneity, timely removal of fallen and weakened trees, thinnings, debarking, and biological control are the most frequently mentioned types of management interventions in the context of combating bark beetles. Although other methods of monitoring, direct and indirect control of insect pests' issue are not widely studied, it is still worth mentioning.

Bark beetles use acoustics in a variety of behaviours, including mate recognition and predator escape, so acoustic techniques could be used to disrupt beetles' behaviours important to their reproduction. A range of experiments taken on Dendroctonus frontalis, D. brevicomis and Ips pini showed that the acoustic technique could substantially lessen bark beetle reproduction and colonization success, deterring or disrupting communication between conspecific or heterospecific species (Aflitto \& Hofstetter, 2014). Insecticides should also be mentioned as a method of the direct insect pest control. Our study area includes mostly boreal forests, and besides, most of the reviewed studies have been conducted in European regions. The use of insecticides is banned in most European countries (Fettig \& Hilszczański, 2015), so its application for management of such pests as I. typographus is not widely studied.

Intensive trapping at stand level could be useful for combating I. typographus in spruce forests. An experiment conducted in northeast Italy showed that using traplogs baited with a pheromone specific to I. typographus and treated with insecticide results in local reduction of beetles' population density and, thereafter, decreased tree mortality (Faccoli \& Stergulc, 2008). 
Although fire treatments are also mentioned in a number of studies, the results show that this type of control measures is usually the most ineffective. A range of experiments in Scandinavian forests, including such measures as controlled burning and partial harvesting of spruce-dominated stands, resulted in increased abundance of I. typographus and P. chalcographus, being at the highest level on plots where burning and harvesting had been combined (Toivanen, Liikanen \& Kotiaho, 2009). Scholars also stated that restoration actions being repeated at consecutive years within a small area might enable the populations to grow to outbreak levels. A similar experiment in the United States was conducted through the comparison of different treatments on three forest units: one received fire treatment, another one experienced thinnings, and the third one received no treatment (Six \& Skov, 2009). Post-treatment mortality of trees due to bark beetles in a non-outbreak phase was the highest in the unit receiving fire treatments.

Besides thinnings, silvicultural activities aimed at combating pests and preventing outbreaks include other forest care measures like fire prevention arrangements, regeneration measures, selecting cutting method appropriate to the nature of forest ecosystems (Zheldak et al., 2015), and sanitary cutting in buffer zones in order to prevent beetle invasion to unmanaged areas (Mezei et al., 2017; Nikolov et al., 2014).

Recommendations on species composition and promotion were formulated by researchers from Central Europe while studying the climate change adaptive management strategies (Marini et al., 2012; Seidl et al., 2009). Firstly, conversion to a species composition close to the potential natural vegetation composition was proposed as it is promised to decrease damages by bark beetles, probably due to reduced homogeneity and increased sustainability of stands. Secondly, it was observed that timber loss due to I. typographus outbreaks in spruce forests was larger in units where spruce was planted on the warmer side of its natural climatic range. Thus, the adaptive management strategy should include avoiding the promotion of spruce outside its historical climatic range.

Proposals addressing the issues of detection and monitoring of forest infestations involve creating high-resolution risk-rating maps using satellite data of forest characteristics and aerial surveys of infestation spots for the forest owners to find and remove colonized trees before the new generation emerge (Jönsson et al., 2012). Social aspects of forest protection management were also studied. Most of them concern public awareness that is aimed to be raised in the field of insect pests and invasive species. It was also stated that society should take part in preparing legislation concerning the 
mentioned issue. Other recommendations include improving interstate exchange of information on invasive species, tightening of border controls and quarantine measures, and developing an early warning system for new non-native invasive species (Andrej et al., 2013).

\section{Economics of invasive forest pests}

Tree diseases dramatically affect the economic value of a forest land and set multiple tasks for forest economics. How to take into account the possible disturbance of forests caused by the insect pest activity when planning the investment project? Is it possible to return the affected areas back to business? How should the government design the policies to implement the efficient economic incentives for harvesting the forests damaged by insect pests? These are only the first major topics to be resolved.

The literature review shows that only a few studies may shed light on some particular aspects of these issues. Usually the problem of economics of invasive forest pests' activity is considered as a secondary problem for general issues of forest disturbances (Holmes, Prestemon \& Abt, 2008).

First attention should be paid to the question of how to include the effect of forest diseases caused by invasive pests into investment analysis. This is a straightforward idea that could be implemented using the basic framework of NPV analysis (Macpherson et al., 2018, 2017). Then it is possible to find a solution to the problem yielding the optimal rotation strategy of harvesting under the condition of tree diseases caused by different sources (Horan et al., 2018; Petucco \& Andrés-Domenech, 2018). A disadvantage of such a holistic and theoretical approach is that it is operationally infeasible because of its complexity and lack of necessary data. There is a need to design some models that could be less general, but more suitable for practical implementation.

One of the most important economic aspect of invasive forest pests is that trade is the main mechanism of transport for many species (Margolis, Shogren \& Fischer, 2005). This is an example of an unobvious market failure, which requires including the estimate of tentative damage into trade tariffs. Despite the fact that such general models were elaborated (Margolis, Shogren \& Fischer, 2005), the examples of its implementation are not known.

A different way to compensate the costs of prevention and abatement against invasive tree species could be elaborated using the concept of forest as public property. In this case, the society should pay for the damage caused by the natural enemies of their property. In most cases, this approach is theoretically supported with the framework 
of Willingness-to-Pay (WTP). The study of WTP for the forest disease control in the UK showed that there is significant public support for financing forest disease control policies, but that depends on forest ownership and the type of control measures used (Sheremet et al., 2017).

It is important to stress out that the techniques of insect pest management implemented in Western countries (Canada, Scandinavia, the USA) could not be easily transferred to the practice of forest management in Russia because of the institutional conditions that are rather different. However, the analysis of such experience is a necessary step for the future progress towards the design of a novel model of the Russian forest sector governance considering the problem of invasive species.

Thus, we showed that despite the fact that there is some theoretical framework to analyse the economic aspects of invasive forest pests' activity, it is still not applicable to make significant contribution to the solution of forest disturbances issues caused by the insects.

\section{Conclusion}

The results of researches discussed above represent an image of the pest combating strategies applied to boreal forests management throughout the world. In general, these management strategies can be divided into direct and indirect control measures. The first ones usually comprise short-term tactics that are aimed at suppressing current beetle infestations. The most commonly studied tactics are biological control measures, debarking, and removal of fallen and weakened trees after any natural forest disturbances. The indirect control, in contrast, is aimed at preventing and reducing the severity of the future bark beetle infestations. The indirect control measures that are widely studied are reducing the homogeneity of forests (both age and species composition), thinning, and other silvicultural activities. Clearly, there are no certain opinions on the effectiveness of mentioned strategies, but, according to the results of our study, fire treatment is most frequently considered ineffective, while applying such methods as debarking, natural enemies control and various silvicultural treatments definitely performs well in the context of the insect pest management.

\section{References}

Aflitto, N.C., Hofstetter, R.W. (2014). Use of acoustics to deter bark beetles from entering tree material. In Pest Management Science, 70(12), 1808-1814. doi:10.1002/ ps.3720. 
Andrej, G., Christo, N., Juraj, G., Jozef, V. (2013). History, Present and Expected Future of Forests in Slovakia. In American Journal of Plant Sciences. doi:10.4236/ ajps.2013.43A090.

Bottero, A., Garbarino, M., Long, J.N., Motta, R. (2013). The interacting ecological effects of large-scale disturbances and salvage logging on montane spruce forest regeneration in the western European Alps. In Forest Ecology and Management, 292, 19-28. doi:10.1016/j.foreco.2012.12.021.

De Groot, M., Ogris, N., Kobler, A. (2018). The effects of a large-scale ice storm event on the drivers of bark beetle outbreaks and associated management practices. In Forest Ecology and Management, 408, 195-201. doi:10.1016/j.foreco.2017.10.035.

Faccoli, M., Stergulc, F. (2008). Damage reduction and performance of mass trapping devices for forest protection against the spruce bark beetle, Ips typographus (Coleoptera Curculionidae). In Annals of Forest Science. Available at: https://www. afs-journal.org/articles/forest/pdf/2008/03/f07142.pdf

Fettig, C.J., Hilszczański, J. (2015). Chapter 14 - Management Strategies for Bark Beetles in Conifer Forests. In F. E. Vega, R. W. Hofstetter (Eds.), Bark Beetles (pp. 555584). San Diego: Academic Press. doi:10.1016/B978-0-12-417156-5.00014-9.

Hlásny, T., Barka, I., Roessiger, J., Kulla, L., Trombik, J., Sarvašová, Z., ... Čihák, T. (2017). Conversion of Norway spruce forests in the face of climate change: a case study in Central Europe. In European Journal of Forest Research, 136(5), 1013-1028. doi:10.1007/s10342-017-1028-5.

Hof, A.R., \& Svahlin, A. (2016). The potential effect of climate change on the geographical distribution of insect pest species in the Swedish boreal forest. In Scandinavian Journal of Forest Research, 31(1), 29-39. doi:10.1080/02827581.2015.1 052751.

Holmes, T.P., Prestemon, J.P., Abt, K.L. (2008). The Economics of Forest Disturbances: Wildfires, Storms, and Invasive Species. Springer Science \& Business Media.

Horan, R.D., Finnoff, D., Berry, K., Reeling, C., Shogren, J.F. (2018). Managing Wildlife Faced with Pathogen Risks Involving Multi-Stable Outcomes. In Environmental \& Resource Economics, 70(3), 713-730. doi:10.1007/s10640-018-0227-y.

Jönsson, A.M., Harding, S., Krokene, P., Lange, H., Lindelöw, Å., Økland, B., ... Schroeder, L.M. (2011). Modelling the potential impact of global warming on Ips typographus voltinism and reproductive diapause. In Climatic Change, 109(3), 695718. doi:10.1007/s10584-011-0038-4. 
Jönsson, A.M., Schroeder, L.M., Lagergren, F., Anderbrant, O., Smith, B. (2012). Guess the impact of Ips typographus - An ecosystem modelling approach for simulating spruce bark beetle outbreaks. In Agricultural and Forest Meteorology, 166-167, 188200. doi:10.1016/j.agrformet.2012.07.012.

Kärvemo, S. (2015). Outbreak dynamics of the spruce bark beetle Ips typographus in time and space. Doctoral thesis. Uppsala. Available at: https://core.ac.uk/download/ pdf/84055832.pdf

Kerchev, I.A. (2014). Ecology of four-eyed fir bark beetle Polygraphus proximus Blandford (Coleoptera; Curculionidae, Scolytinae) in the west Siberian region of invasion. In Russian Journal of Biological Invasions, 5(3), 176-185. doi:10.1134/ S2075111714030072.

Kerchev, I.A., Kryukov, V.I., Iaroslavtseva, O.N., Polovinko, G.P., Tokarev, I.S., Glupov, V.V. (2017). The first data on fungal pathogens (ascomycota, hypocreales) in the invasive populations of four-eyed fir bark beetle Polygraphus proximus Blandf. In Russian Journal of Biological Invasions, 8(1), 34-40. doi:10.1134/S2075111717010040.

Macpherson, M.F., Kleczkowski, A., Healey, J.R., \& Hanley, N. (2018). The Effects of Disease on Optimal Forest Rotation: A Generalisable Analytical Framework. In Environmental \& Resource Economics, 70(3), 565-588. doi:10.1007/s10640-016-0077-4.

Macpherson, M.F., Kleczkowski, A., Healey, J.R., Quine, C.P., Hanley, N. (2017). The effects of invasive pests and pathogens on strategies for forest diversification. In Ecological Modelling, 350, 87-99. doi:10.1016/j.ecolmodel.2017.02.003.

Margolis, M., Shogren, J.F., Fischer, C. (2005). How trade politics affect invasive species control. Ecological Economics. In The Journal of the International Society for Ecological Economics, 52(3), 305-313. doi:10.1016/j.ecolecon.2004.07.017.

Marini, L., Ayres, M.P., Battisti, A., Faccoli, M. (2012). Climate affects severity and altitudinal distribution of outbreaks in an eruptive bark beetle. In Climatic Change, 115(2), 327-341. doi:10.1007/s10584-012-0463-z.

Marini, L., Økland, B., Jönsson, A.M., Bentz, B., Carroll, A., Forster, B., ... Schroeder, M. (2017). Climate drivers of bark beetle outbreak dynamics in Norway spruce forests. In Ecography, 40(12), 1426-1435. doi:10.1111/ecog.02769.

Mezei, P., Blaženec, M., Grodzki, W., Škvarenina, J., Jakuš, R. (2017). Influence of different forest protection strategies on spruce tree mortality during a bark beetle outbreak. In Annals of Forest Science, 74(4), 65. doi:10.1007/s13595-017-0663-9.

Nikolov, C., Konôpka, B., Kajba, M., Galko, J., Kunca, A., Janský, L. (2014). Post-disaster Forest Management and Bark Beetle Outbreak in Tatra National Park, 
Slovakia. In Mountain Research and Development, 34(4), 326-335. doi:10.1659/MRDJOURNAL-D-13-00017.1.

Panaiotov, M., Bebi, P., Tsvetanov, N., Aleksandrov, N., Laranjeiro, L., Kulakowski, D. (2015). The disturbance regime of Norway spruce forests in Bulgaria. In Journal Canadien de La Recherche Forestiere [Canadian Journal of Forest Research], 45(9), 1143-1153. doi:10.1139/cjfr-2014-0505.

Pasztor, F., Matulla, C., Rammer, W., Lexer, M.J. (2014). Drivers of the bark beetle disturbance regime in Alpine forests in Austria. In Forest Ecology and Management, 318, 349-358. doi:10.1016/j.foreco.2014.01.044.

Petucco, C., Andrés-Domenech, P. (2018). Land expectation value and optimal rotation age of maritime pine plantations under multiple risks. In Journal of Forest Economics, 30, 58-70. doi:10.1016/j.jfe.2018.01.001.

Rew, L.J., Johnson, M.P. (2008). Response to Change: Understanding How Forest Management Activities Affect Nonindigenous Species Occurrence and Distribution. In Journal of Sustainable Forestry, 27(3), 275-302. doi:10.1080/10549810802256247.

Schlyter, P., Stjernquist, I., Bärring, L., Jönsson, A.M., Nilsson, C. (2006). Assessment of the impacts of climate change and weather extremes on boreal forests in northern Europe, focusing on Norway spruce. In Climate Research, 31, 75-84. doi:10.3354/cr031075.

Seidl, R., Schelhaas, M.J., Lindner, M. \& Lexer, M.J. (2009). Modelling bark beetle disturbances in a large scale forest scenario model to assess climate change impacts and evaluate adaptive management strategies. In Regional Environmental Change, 9(2), 101-119. doi:10.1007/s10113-008-0068-2.

Sheremet, O., Healey, J.R., Quine, C.P., \& Hanley, N. (2017). Public Preferences and Willingness to Pay for Forest Disease Control in the UK. In Journal of Agricultural Economics, 68(3), 781-800. doi:10.1111/1477-9552.12210.

Six, D.L., Skov, K. (2009). Response of bark beetles and their natural enemies to fire and fire surrogate treatments in mixed-conifer forests in western Montana. In Forest Ecology and Management, 258(5), 761-772. doi:10.1016/j.foreco.2009.05.016.

Subramanian, N., Bergh, J., Johansson, U., Nilsson, U., Sallnäs, O. (2015). Adaptation of Forest Management Regimes in Southern Sweden to Increased Risks Associated with Climate Change. In Forests, Trees and Livelihoods, 7(1), 8. doi:10.3390/ f7010008.

Thom, D., Rammer, W., Seidl, R. (2017). The impact of future forest dynamics on climate: interactive effects of changing vegetation and disturbance regimes. In Ecological Monographs, 87(4), 665-684. doi:10.1002/ecm.1272. 
Thorn, S., Bässler, C., Bußler, H., Lindenmayer, D.B., Schmidt, S., Seibold, S., ... Müller, J. (2016). Bark-scratching of storm-felled trees preserves biodiversity at lower economic costs compared to debarking. In Forest Ecology and Management, 364, 10-16. doi:10.1016/j.foreco.2015.12.044.

Toivanen, T., Liikanen, V., Kotiaho, J.S. (2009). Effects of forest restoration treatments on the abundance of bark beetles in Norway spruce forests of southern Finland. In Forest Ecology and Management, 257(1), 117-125. doi:10.1016/j. foreco.2008.08.025.

Zheldak, V.I., Malakhova, E.G., Proca, I. Iu. (2015). Sovershenstvovanie lesovodstvennykh mer soderzhaniia i ispol'zovaniia elovykh lesov, povysheniia ikh ustoichivosti i snizheniia otritsatel'nykh posledstvii patologii [Improving silvicultural measures for the maintenance and use of spruce forests, increasing their resilience and reducing the negative consequences of pathology]. In Lesotekhnicheskii zhurnal [Forestry Journal], 2, 44-65.

\title{
Экономические последствия вспышек насекомых-вредителей в бореальных лесах: обзор литературы
}

\author{
Е.Д. Иванцова, А.И. Пыжев, Е.В. Зандер \\ Сибирский федеральный университет \\ Россия, 660041, Красноярск, пр. Свободный, 79
}

\begin{abstract}
Вспьшки насекомых-вредителей считаются одним из наиболее разрушительных видов естественных лесных нарушений. Серьезность таких вспышек в последние годы быстро возрастает из-за проиесса глобального потепления, который влияет на скорость размножения вредителей и диапазон их естественного распространения. Особое значение имеют экономические последствия данных видов нарушений. Несмотря на обширные исследования экологии древесных фитофагов, вопросы оценки экономического ущерба и формирования механизмов его минимизации изучены слабо. В данной статье представлен обзор исследований, посвященных проблеме вредных воздействий насекомых - вредителей леса, классифицированных по их локализации. Область исследования включает в себя в основном бореальные леса, расположенные в ряде европейских стран, США, Канаде и России. В исследовании обсуждаются инструменты, применяемые для предотвращения упомянутых выше нарушений и смягчения соответствуюших негативных последствий. Несмотря на то, что существуют теоретические подходы к анализу экономических последствий поражения лесов вредителями, они пока не могут найти практического применения.
\end{abstract}

Ключевые слова: экономика леса, лесные нарушения, вспьшки насекомых-вредителей, изменение климата, бореальнье леса, управление лесами. 
Статья подготовлена при финансовой поддержке гранта Президента Российской Федеращии для поддержки молодых российских ученых № МК-3482.2018.6 (Анализ взаимосвязи климатических изменений и распространения дендрофагов, экономических аспектов проблемы вспышек насекомых-вредителей в бореальных лесах) и проекта Российского научного фонда № 19-77-30015 (Классификащия основных стратегий борьбы с дендрофагами).

Научная специальность: 08.00.05 - экономика и управление народным хозяйством. 